\title{
ENTERING HIGHER EDUCATION AFTER 30: WHAT CAN BE LEARNED FROM BIOGRAPHICAL NARRATIVES OF NON-TRADITIONAL STUDENTS
}

\author{
LEANETE THOMAS DOTTA, \\ CARLINDA LEITE, \\ AMÉLIA LOPES
}

\begin{abstract}
The needs of the market and of knowledge society, combined with democratic ideals, have justified policies that encourage the adult population to continue their studies. Portugal has been following this political movement, which in turn drives non-traditional students to higher education. In order to uncover the reasons that lead these students to enter higher education and the challenges it poses to them, research was conducted using biographical narratives. These narratives revealed the existence and effects of intrinsic motivations related to the satisfaction of learning and to the pleasures of taking part in stimulating activities and of achieving or overcoming something. They also showed the importance of having strategies to combat dispositional, situational, and institutional barriers in order to prevent non-traditional students from dropping out.
\end{abstract}

Keywords

higher education, non-traditional students, biographical narratives 


\section{Introduction}

The demands of the market increasingly acknowledge the need for broader training programs that allow for continuous adjustments in face of the challenges presented by the knowledge and technological society. This situation has justified policies aiming to extend training for adult students and initiatives that balance discourses regarding democratization with the needs of knowledge societies and economic interests (e.g., the 2000 Lisbon Strategy, the Europe 2020 Strategy, and the 2030 Agenda). In these initiatives, the expansion of participation in higher education by specific groups of the population is privileged (Roberts, 2011; Souto-Otero \& Whitworth, 2017).

Since 2005, Portugal has been taking measures in order to expand the ways of accessing higher education (HE) for students over 23 years of age. Among these measures, the possibility to acknowledge professional experience and post-secondary training through credit attribution, the possibility to enter this level of education by taking specific tests for those over the age of 23 who do not have the qualifications, as well as for those with adequate post-secondary training, the creation of the student worker status, and the possibility of access for students with technological specialization courses stand out. In 2014, following the creation of higher education technical professional courses - short HE courses that do not confer a degree, only a diploma - the conditions to access these courses were specified (Thomas Dotta et al., 2019). As a result of these measures, in 2016, $33.5 \%$ of people between 30 and 34 years old living in Portugal held a HE degree or equivalent. However, lacking more consistent support measures, the system's capacity to attract and retain older students, working students, and students from underrepresented socioeconomic groups in HE remains reduced.

In Portugal, non-traditional students (NTSs) are, generally, over 23 years old, come from different training paths, and access HE through so-called "special access contests." This characterization is, however, reductive (Ferreira, 2011). Other important characteristics have already been identified: they are hard workers; they are attending HE for the first time and have been away from the education system for some time; they enjoy worker-student status; and they are usually the first in their family to enter HE (Brás et al., 2012; Pascueiro, 2009).

Although in some countries the problems of NTSs emerged in the 1970s and 1980s and, in those contexts, it is possible to speak of a process of "adultification" in HE (Schuetze, 2014), in other countries this process is recent. In Portugal, NTS access has been more significant since the 2006/2007 academic year, when for the first time $15 \%$ of students enrolled in the first year were over 23 years old; Fragoso and Valadas (2018) called this the "silent 
revolution" (p. 20). Until then, the education system offered few opportunities for those who left school prematurely. Over the following years, in the public HE system, the percentage of NTS enrollment varied between a minimum of $6.5 \%$ and a maximum of 10.5\% (Mangas et al., 2019). However, despite the progressive increase in students fitting this profile, studies on their trajectories in HE indicated dropout rates of 50\% (Engrácia \& Baptista, 2018).

With this problematic background as a reference, this study was developed aiming to explore and understand the reasons NTSs in Portugal enter HE, the challenges it poses to them, and the strategies they use to complete their academic career at this education level. Taking this into account, the study, using a biographical-narrative approach, sought to answer the following questions: What reasons to enroll and to continue studying do NTSs express in their life stories? What challenges do they face, and what strategies do they use to face them?

Research focused on these questions allowed for an update on the reasons why NTSs access HE courses and revealed possible effects of policies that intend to stimulate the attendance of students over 23 years old.

\section{Non-traditional students (NTSs)}

Criteria with different types of relationships among themselves have been used to define NTSs: educational biography; entry paths and study modes (Schuetze \& Slowey, 2002); socioeconomic and sociocultural factors (Holmegaard et al., 2017); demographic factors; and factors resulting from national and transnational policies (Souto-Otero \& Whitworth, 2017). The complexity and diversity of the NTS characteristics suggest "different degrees of non-traditional" (Schuetze, 2014, p. 38), or the use of flexible and adaptable concepts that are not restricted to an idea of opposition to the students considered traditional (de Almeida et al., 2016). In this perspective, the idea of NTSs includes older students, students with special education needs, women, the first in their families to enter HE, working class students, students belonging to cultural minorities, migrant populations, etc. and/or, in an associated way, those whose inclusion in HE is hampered by structural factors (Bamber, 2008; Merrill \& Johnston, 2011).

Considering HE policies and access conditions in Portugal, where the study that supports this article was conducted, and the global movement to expand HE access to adult students (Thomas Dotta et al., 2019), the discussions and reflections developed here are focused on entry paths and age. However, this option does not disregard that these students may share other characteristics and does not intend to reduce the complexity of this issue to age-related situations. 
Literature on NTSs, centered on late admission to HE, generically refers to them as "mature students" (Amorim, 2018; Broadhead, 2020; Pearce, 2017). The age that defines these students varies from country to country, but they are at least 21 years old (Baptista, 2013; Broadhead, 2020; Heagney \& Benson, 2017). In Portugal, it corresponds to students over 23 years of age (M23).

The central characteristics attributed to them are: having professional and family responsibilities; a fragmented trajectory in formal education or one with a long period of hiatus; coming from low income and education level family settings; and being women (Davies \& Williams, 2003; Heagney \& Benson, 2017; Merrill, 2014). These characteristics evidence multiple roles and therefore, generally, not much time to dedicate to studies. Additionally, for some of these NTSs, studying can result in tiredness or in family, academic, and professional conflicts, that is, in an increased emotional and financial burden (de Almeida et al., 2016; Kirby et al., 2004; Osborne et al., 2004).

Democratization policies focused on HE have taken into account the need to meet the demands of knowledge societies and of the economic sector, two aspects that are central dimensions in the case of NTSs (Thomas Dotta et al., 2019). This global political movement, which has been intensifying since the 1990s through national and regional initiatives, such as the creation of the European Higher Education Area, created conditions for increased NTS access, though the conditions are not always as democratic as the political discourse would indicate (Amorim, 2018).

On the other hand, the academic literature points to a set of personal, professional, and social factors that motivate NTSs to enter HE. The search for personal development, personal satisfaction, the opportunity to interact with other people, and new experiences, and the desire to give new direction to their lives (Novotný et al., 2019; Osborne et al., 2004; Taylor \& House, 2010) are among the main personal motivations. Professionally, the main motivating factors are the search for opportunities to enter a new professional field, career progression, improvement and broadening or acquisition of knowledge, and an increase in remuneration (Mangas et al., 2019). The improvement of social status by earning a HE diploma, the desire to become a better citizen, and the wish to set an example to the following generations in their families (Barros et al., 2019; Quintas et al., 2014) are the main social motivations.

Despite the strength of these students' motivations and the fact that they generally show a greater sense of responsibility and commitment to studying, their characteristics put them at an unequal or disadvantageous position (de Almeida et al., 2016; Kirby et al., 2004). In addition, they face at least three types of barriers: dispositional, institutional, and situational (Cross, 1981), which may involve interconnected dimensions. 
Institutional and $\mathrm{HE}$ cultures are based on the long history of the university system's functioning. Most of the population deals naturally with the consolidated dynamics. However, to NTSs, these same dynamics can pose real challenges (Holmegaard et al., 2017). According to the aforementioned studies, the reduced time that NTSs spend within the context of HE institutions, due to their other responsibilities, makes it difficult to establish relationships with colleagues and even to get close to teachers. This may result in these students going through a solitary academic journey (Gilardi \& Guglielmetti, 2011), adding to the so-called intergenerational shocks (Knapper \& Cropley, 2000; Reay et al., 2002) that may mitigate relations with younger colleagues. Curricular contents, pedagogical work modes, and the processes of evaluation and teaching and learning can also be an obstacle, as they are generally organized taking into account the characteristics of students who fit the profile of HE's usual "clients." Failure to adapt this level of education to new audiences can contribute to NTSs being perceived and perceiving themselves as lacking the potential, ability, or motivation to participate (Burke, 2013). The institutional inability to meet the needs of a student population with increasingly diverse characteristics (Broadhead, 2018) has an effect on the success of these students' academic trajectory.

At the interface between motivations and challenges are the NTSs' agency capacity, "agency" being understood here as a decision-making power (Priestley et al., 2015), and the negotiation strategies they develop, the decisions they make, and the actions they take in order to achieve social and academic integration, as well as their resilience (Holmegaard et al., 2017; Merrill, 2015). If, on the one hand, it cannot be disregarded that agency is inserted in a social context, on the other hand, it implies an active involvement of the subject. The study this article refers to was intended to determine how adult students get involved with the workload that is requested of them and with academic life, and how they face the challenges they encounter in relation to the reasons that motivated their entry in HE.

The idea of student motives being understood in connection with the experiences and challenges they felt over the course of life (Thunborg et al., 2013) derives from the biographical-narrative perspective. For West (1996), motives are the reasons and meanings that people attribute to their actions and are dynamic, changeable, and interconnected. The use of biographies makes it possible to understand the interaction between structure and agency in the past, present, and future of a life course (Merrill, 2015). 


\section{Biographical-narrative methods and studies on NTSs}

The biographical-narrative approach has increasingly been used in the field of social and human sciences, and this trend has been followed in studies involving NTSs (Merrill \& Johnston, 2011; Mertova, 2013). Focusing on lived experiences and on the meanings that the subjects attribute to these experiences, this method allows for the apprehension of the complexities of the interactions between person and context. In methodological terms, its pedagogical and philosophical potentials stand out and, in terms of analysis, its ecological dimension.

With Bolívar Botía (2008), we recognize that though each individual knows their life better than anyone else, sometimes that life is also unknown to the individual. It is in this sense that Goodson et al. (2010) emphasize that the stories we tell about ourselves and about our lives, understood in their complexity, are fundamental to our learning. This happens when there is an intense involvement in the process; when the participants reflect on their experiences, they themselves build, from themselves, knowledge (Savin-Baden \& Van Niekerk, 2007). In these cases, the participant-narrators reconstruct themselves retrospectively (Elbaz-Luwisch, 2005) and interpret their own lives and/or the lives of others in a learning process based on dialogue and reflection (Thomas Dotta \& Soares, 2015). Bruner (1991) stated that a situation or event becomes narrable when it escapes the subject's normal standards and leaves a mark. The act of narrating contributes to making these situations or events understandable to the subject, since they do not narrate what happened, but what happened to them.

The biographical-narrative approach, in a philosophical dimension, is a privileged way to highlight "silent/silenced" voices of minority groups (Rodriguez \& Cho, 2011). This is a perspective that places the voices of NTSs within the scope of the right to be heard, to have something to say, to be acknowledged, and to have acknowledged the importance of exploring the experiences of these students, resulting in more complex understandings. This perspective implies an open listening posture by the researchers to ensure that the participant's voice is heard and that the final result is not the researcher's exclusive creation (Polkinghorne, 2007).

Methodologically, biographical researchers "offer rich insights into the dynamic interplay of individuals and history, inner and outer worlds, self and other" (Merrill \& Johnston, 2011, p. 1). According to Clandinin et al. (2017), the three-dimensional character of narrative research, where temporality, sociality, and place are articulated, makes it possible to interpret the involved phenomena in an ecological way. In the same way, Bolívar Botía (2002) defends the need to mobilize a binocular vision, that is, to be attentive to the narrator's internal reality portrait and inscribe it in an external context that indicates 
meaning and sense to the experienced reality. Dhunpath (2000) understands the biographical approach as the only authentic way to understand how motives and practices reflect the deep intersection of institutional and individual experience in the postmodern world. Therefore, the life stories of NTSs are not simply a kind of picture that we look at and learn about; they are a complex process where life and the self are simultaneously producers and products of history (Thomas Dotta \& Soares, 2015).

Following the aforementioned general precepts, biographical-narrative research with NTSs provides a more complex understanding of these students regarding their life courses and how they interact in social, economic, personal and social arenas (Merrill \& Johnston, 2011).

West (1996), through the biographical approach, discussed the complex relationship between professional and personal motivations for late entry in HE. The author concluded that while people may initially present a professional justification for their studies, influenced by the power of instrumental ideology in the broader culture, professional motivation may be rooted in deeply personal concerns.

The experiences of women in HE regarding gender culture, which includes the universities themselves, were discussed by Edwards (1993). Regarding gender issues, Johnston and Merrill (2005) also used the biographical method to explore the experiences of students belonging to the working class.

A typology of NTSs in Europe, in the Weberian sense, was created through the studies of Bron and Lönnheden (2004), identifying three types of students: hesitators, postponers, and formalizers. Hesitators, usually the first in their family to enter HE, did well in school and, though they had the opportunity to follow their studies in HE, they hesitated to do so and made the decision later in life. Postponers stem from families with academic tradition but entered HE when they were older. Formalizers are workers who end up enrolling in $\mathrm{HE}$ for professional reasons.

The meanings and experiences of retention and dropout of NTSs in HE are discussed by Merrill (2015), who argues that, despite being viewed negatively by policy makers who perceive student abandonment of $\mathrm{HE}$ as failure, dropping out does not always have to be a negative act, as these students still reference the benefits they obtained in terms of learning, building of identity, and self-development.

Tumuheki et al. (2016), within the scope of NTS motivations to enter HE, identified multiple and multifaceted motivations in Uganda. The influences of the sociocultural context of Ugandan society and the social perceptions of HE stood out as factors that shape the NTS motivations to improve their educational qualifications. Motivations of an extrinsic nature related to rewards in the sociocultural environments where the students were inserted before entering HE were also highlighted. 
Broadhead (2020), when exploring the experiences of an NTS, presents the difficulties encountered by the student in relation to time management, pedagogical work modes, and evaluation. Failure to communicate with teachers resulted in frustrations and brought the student closer to dropping out of the course. Based on these results, the author discusses the need for institutions and teachers to adapt to NTS characteristics.

In the study that supports this article, the choice of the method and the definition of the research paths followed are grounded on the assumptions that scientific knowledge must be generated from reality and improve people's lives (Suárez-Ortega, 2013) and that biographical-narrative research is research conducted with NTSs and not about them (Atkinson, 2009).

\section{Methodological design}

In order to explore and understand the reasons for joining HE, the challenges that are faced, and the strategies that NTSs use to complete their academic paths in HE in Portugal, the biographical narratives of two NTSs were analyzed. This choice was motivated by the richness of the data (Liamputtong \& Ezzy, 2005), as opposed to representativeness, and by the narrative competence (Gudmundsdottir, 1996) of these two students. Furthermore, the option to analyze the narratives of two life stories is grounded in the argument that individual stories "retain more of the noise of real life" (Hodkinson \& Hodkinson, 2001, p. 3) than a thematic approach to a bigger number of narrative interviews.

In the biographical-narrative approach, epistemological and ethical issues intertwine (Molina, 2011). When the researcher enters the participants' contexts, even for a short period, that researcher becomes part of their settings, thoughts, and words, which requires strict ethical surveillance from the researcher. Therefore, the process of collecting the interviews involved the establishment of a narrative contract (Bolívar Botía, 2008) in which the deontological rules of the research were clarified and the informed consent form signed. The interviews were conducted in a location chosen by the interviewees and lasted approximately two hours; they occurred in a dialogic environment (Freire, 2003), permeated by a self-reflection process.

The recorded interviews were given back to the interviewees after being transcribed. They were unaltered and analyzed narratively (Polkinghorne, 1995). The narrative analysis went through the process of "narrative configuration" (Polkinghorne, 1995), that is, the events diachronically narrated by the interviewees were drawn and integrated into a chronologically organized whole, based on the following paths: (1) the inclusion of descriptions of the cultural contexts; (2) attention to the embodied nature of the protagonist; 
(3) the relevance of other significant people who affect the actions and objectives of the protagonist; (4) the historic continuity of the characters; and, finally, (5) the production of a comprehensible story that can make understandable its complexities and particularities. The narrative analysis focuses on the particular characteristics of the experiences from which a story that organizes and gives meaning to the data, taking into account the objectives of the study, is configured. The result is a retrospective explanation that articulates the narrated events, the interpretation of which reveals and clarifies their meanings (Polkinghorne, 1995, 2007).

\section{The Narratives}

This session presents the narratives of André and Julia, which result from organizing the data obtained through the biographical-narrative interviews, focusing on the reasons for entering $\mathrm{HE}$ and on the challenges they face and the strategies they employ to cope with them.

\section{André}

André entered the job market even before completing compulsory education, which at the time was the 9th grade. He lived in the interior of the country, where the valorization of early work surpassed the importance of studies. In Portugal, following the revolution that restored the democratic state in 1974, the objective of ensuring compulsory education, initially for six years, was established. In 1986, the Basic Law of the Educational System extended compulsory education to the 9th grade; in 2009, it extended to the 12th grade. André was motivated to start his professional life not exactly by financial need, but primarily by the desire to obtain autonomy as a young man who, at the age of 15, could, through his work, satisfy small material desires and "go to places of entertainment," expenses his family was unable to support. In the beginning, André conciliated work with his studies by attending classes in the evening; with some difficulties, he managed to complete compulsory education (he had previously been retained once and also attended private education). These difficulties rose from the dynamics of arranging work and evening classes and from the implications of a period of curricular reforms that resulted in the implementation of new study plans (Decree-Law No. 286/89, 29th August). On the other hand, in the sociocultural context, André was "different" from all the other people his age who had restricted themselves to completing only the initial six years of schooling. These difficulties, added to the increased demands of work, where his schedule at the time involved rotating shifts, removed André from school, but did not exclude him from other training opportunities. In the close and wider family 
context, where the education levels were very low, the incentive to study came especially from his father, who believed that studying meant better jobs and, consequently, better living conditions.

André, stating that there was a moment when his work and studies could no longer be arranged, therefore leading him to drop out, recalls, reflecting: "it's funny, in a way, I was always connected to one course or another." He started a correspondence course, which, though not completed, enlightened him through many hours of studying, with André often "falling asleep on the books." He took an English course in the same fashion. Regular reading of newspapers in the workplace and subscribing to monthly magazines kept him informed on various subjects. These were financial investments made possible by a salary "above normal for the time," coupled with a desire to learn more about the themes that emerged in his professional context. Distance learning in one of its initial versions, correspondence, was the way André found to access knowledge at a time when, in Portugal, access to and use of the internet was still incipient. Accounting for regional asymmetries, less than $20 \%$ of the population used the internet in the early 2000s (Da Cruz, 2012).

The convergence of work skills and informal studies led André to start autonomous, informal, and parallel work, which constituted a second source of income.

In addition to his professional career, André also started a family and felt completely fulfilled. However, as time went by, he realized "the job was no longer fulfilling." He had "already exploited it to the fullest" of what his knowledge allowed, both in his formal work, where he had reached the limit of progression, and his informal work. This awareness made him consider seeking more solid formal training. The search for courses that could help to base and expand the knowledge he possessed put him in contact with a professional school, where he started taking some certified short courses. These courses, fundamentally practical, seemed to widen the gap André felt, and the need to understand what was "behind" the practice increased. It was at this time that he became aware of the "New Opportunities Initiative." This government program was launched in 2006 with the aim of facilitating access to education and to professional training equivalent to the 12 th grade, especially for students who dropped out of school upon completing the 9th grade. André obtained the training that gave him equivalence to the 12th grade in this way, which allowed him to enter a technological specialization course. The courses are post-secondary, short duration, non-higher education courses that have among their purposes to allow the continuation of training. André completed this training course through daily attendance of evening classes and, as a whole, they allowed him to access HE. The professional school he attended had a protocol with a university allowing direct entry to a university course. André did not hesitate: "that was when I saw a great 
opportunity to enroll in the university and feel fulfilled." This entry route is part of the special access contests that have been in place in the country since 1999, as part of the national policies to expand access to HE (Thomas Dotta et al., 2019). It was the culmination of a journey that took shape as the fulfilment of the desire to acquire and expand knowledge. André lived in a routine that demanded the arrangement of formal work, family obligations, and informal work, which he continued to do over the weekends with his studies, with the conviction that "the greater the knowledge, the greater the access to better living conditions." An improvement of conditions, for André, was connected to the acquisition of knowledge, and the material dimension was a consequence. Entering the university was a turning point in André's professional life. It opened the doors to being an educator at the vocational education institution where he had completed his training course.

André's reaction when he started the course was "why did I stop studying!?" This reaction involves, on the one hand, genuine regret for not having pursued his studies in due time and, on the other hand, genuine amazement with the "world" that is academic life in terms of knowledge and relations. This perspective underlies André's advances and setbacks in his new role as a student. The Portuguese Labor Code, in 2009, regulated the student worker status. This status safeguards conditions for student workers to reconcile the work world with the study world. In the work context, student workers have the opportunity to organize their schedules in order to be able to attend classes and evaluations. In the educational context, there are specific rules regarding the frequency of classes, the minimum number of subjects, and the prescription regime, among others. Under this statute, André organizes and manages his time between his work and his studies. He acknowledged that he is not able to dedicate much time to studying beyond the classes he is able to attend. He occasionally meets with some colleagues in the same situation to study, but still, "I needed to study more." He attributes the difficulties faced to basic knowledge that he was not able to assimilate in basic education. André tries to have a close relationship with the teachers, but acknowledges that, as he does not attend classes systematically, distance is inevitable. Between the demands of his job and his difficulties with the contents, only a few subjects are completed each year and, slowly, with a few interruptions, André carries on without thinking of giving up, taking the time he needs to complete the course. He perceives the university context as the space where he will be able to fill the knowledge gaps that he feels he has. "Given my maturity, in every way, it is the apex of knowledge, in relationships, in socializations, it is the apex of our life." "I didn't think it was like that, only when I joined did I gain this notion." "I never miss the opportunity to tell young people, my students, everyone, without exception, that they should enter the world of higher education." 


\section{Julia}

Julia lived in a supportive and encouraging family environment regarding studies, though her parents had only completed the 4th grade. Julia and her older brother's childhood and adolescence was spent in a coastal city, which, according to her, "though simple, lacked nothing." She relates the professional stability of her parents to some financial autonomy that allowed her to have access to a set of cultural assets. The great closeness and dialogue that existed in the family, in spite of an education that she considers "rigid and traditional," permanently fed the valorization of studies and training. Julia's educational path went on regularly until the end of her secondary education, always closely supervised, especially by her mother. Admission to HE was part of the plan and Julia believed that, like her brother, she would be able to choose any course she wanted, regardless of any conditions. However, when it was time to make the final decision, she was faced with limitations imposed by her parents. Her parents made numerous arguments to keep her studying without leaving. Some were related to finances, because she would need to leave her household, but mainly they had to do with the fact that she was a woman. Julia's understanding of this resulted from a retrospective look at what happened, since, at the time, she accepted the situation without major issues or oppositions. Thus, Julia joins HE after choosing the "possible" course and not the "desired" one. The great encouragement and effort from her mother for Julia to enter HE, often in opposition to her father's will, was, in Julia's interpretation, due to the great appreciation and admiration that her mother showed for women "doctors," at a time when having a degree already qualified one, socially, with the title of doctor. At the beginning of the course, despite her "natural shyness," Julia became involved in the academic environment, mainly in the relationships with her colleagues. However, the months went by and she "fell into reality" and, in Julia's words, amid an expression of regret, "I didn't recognize myself in the course and gave up." Soon afterwards, she entered the job market and started "living her life with a sense of accomplishment," a feeling that "compensated" for the fact that she had not stuck to the plan and obtained a higher education degree. She started a family, in her opinion very early, and once she had children her time was totally occupied by and shared between dedication to family and work. The demand implied in the education of her children led Julia to be additionally involved with what she calls an "informal study" of child development. Her children grew up and this dedication became less demanding. In the professional context, Julia was gradually taken over by demotivation. She performed her duties without having to "think too hard," and she no longer "found any challenge" in her work routines. On the other hand, in the context of career progression, she had also reached the attainable limit, considering her academic qualifications. The reduction of the challenges in the conjunction 
of family and professional life opened space for Julia to start "missing something." Julia concluded that she "needed to find new challenges" and the possibility of taking a HE course rose. However, concerns about time management, logistics, the idea that her "time had passed" and, above all, the concern about not "neglecting family and professional life" delayed her decision. In her work context, Julia was one of the people who had more experience; her knowledge was often required, even by colleagues who had higher professional status than she did. Although she no longer felt challenged at work, the workload increased. Conflict situations resulting from this framework culminated in Julia's decision to earn a HE degree and thus seek career progression. Julia joined HE through special access contests after almost 30 years away from academic life. Access to HE in Portugal is made possible through contests that are distinguished in two major groups: the general regime that covers students who have just completed secondary education and the special access contests that take into account a set of specific characteristics of the candidates. Among these special access contests is the "special contest for students over 23 years old," the category where Julia was inserted. This contest involves the appreciation of the educational and professional curricula, a written test, and an interview. For Julia, the biggest challenge was the "especially adequate tests designed to assess the ability to attend higher education for those over 23 years old." Afraid that she might not succeed in the written test, Julia dedicated herself to study through tutoring. This experience was lived by Julia intensely, as "it made me feel that I was able to do it" and gave her confidence to follow the path that lay ahead. By going through the necessary access procedures, admission to HE was ensured. Julia benefited from the student worker status; since the organization of her working time allowed it, she set a personal goal to attend all the classes. She felt motivated and enthusiastic despite knowing that the management of multiple functions would be very demanding. However, the adaptation to the new reality was complex and she confessed that, in the beginning, "the only thing that kept me going was not allowing myself to give up a second time." The biggest difficulties she faced were related to the workload she had in the different subjects, which took away a large part of the time she used to dedicate to her family. Julia thought that although the emphasis given by teachers to autonomous work had training benefits, it exceeded the available time, considering the sum of all subjects. It was viable only for those who could dedicate themselves exclusively to their studies. In spite of the safeguards provided by the student worker status, she felt the teachers did not concern themselves with the specific characteristics of these students. Over time, Julia found strategies for dealing with the work volume. Her level of demand was based on the value she attributed to each subject and guided how much time she would dedicate to each of them. On the other hand, in the family 
context, she tried to ready the family to face a period where her time of dedication would be a little reduced, but "without ever losing quality." In the relational sphere, though difficulties also existed, they affected Julia differently. Julia recalled the proximity of the relationships with colleagues that she experienced in her first experience in HE. She remembered the energy and the disposition to have conversations "before, during and after classes." Julia knew it would be different; she did not expect to interact and relate to her younger colleagues in the same way. However, she did not expect some attitudes by her colleagues to test her patience. She often thought "I can't be wasting time with these issues." As a reflection, Julia acknowledges that if, on the one hand, she wants to make use of every minute in the classroom to avoid having to take this time off from her other duties, on the other hand there is a certain frustration due to not having completed the course when she was still young. Julia considers her relationships with teachers as positive, but not close. With the exception of one or two teachers, she does not remember having an individual conversation with them. Though she recognizes that it is also her responsibility to seek a closer relationship, she says she has not felt openness from the teachers. Despite all the difficulties and challenges faced, Julia feels satisfied when she thinks that she is already finishing her degree, and she is considering enrolling in a master's degree. She believes her difficulties are mainly due to "having missed her time," but that she is learning a lot from the experience, in addition to the scientific knowledge.

\section{Discussion and Conclusion}

Research has shown that the reasons that lead NTSs to HE are multiple, multifaceted, and different for each individual (Osborne et al., 2004; Taylor \& House, 2010; Tumuheki et al., 2016). Focusing on André's case, though the influences of his context led him away from school early to enter the labor market, his path is predominantly marked by the constant search for knowledge. Valuing knowledge, as a way to both improve his professional life and achieve personal satisfaction, motivated his choices, and led him to HE. Julia, in turn, has a trajectory built in a context where obtaining a HE degree was almost a requirement. Although the limitations imposed by her family most likely led her away from her initial academic path, the objective of completing a HE course was to be achieved, albeit belatedly. The search for personal and professional challenges marked Julia's path back to HE.

As shown by André and Julia's biographical-narratives, they followed very different paths, but these paths intersect in valuing $\mathrm{HE}$ as a form of personal and professional fulfilment and in the search for a change in status and direction (Osborne et al., 2004). Returning to the research questions - What 
reasons to enroll and to continue studying do NTSs express in their life stories? What challenges do they face and what strategies do they use to face them? - both of their motivations were intrinsic, related to learning satisfaction and the pleasure of participating in stimulating activities and achieving or overcoming something. In this sense, this research confirms the conclusions reached by Novotný et al. (2019) when they point to the relationship of knowledge and learning with fulfilment.

The research also showed that the challenges NTSs face in order to complete a HE course have different impacts and conflicts. Comparing the research results with the three types of barriers identified by Cross (1981) institutional, dispositional, and situational - this study showed that policies to encourage further studies were important so that these two adults could access $\mathrm{HE}$ training. Institutional barriers, such as issues regarding admission requirements, have been lowered.

Dispositional barriers were related to the students' perception of their own learning capacities and their established relationships with teaching/ learning processes. André recognized that one of the main challenges he faced was the difficulties with some contents due to the lack of consistent previous knowledge. He needed much more time on each subject to be able to advance.

Situational barriers were also present in the paths of these two NTSs due to the lack of time to study, as these adult students were workers with families and other social responsibilities. However, they found a balance that allowed them to continue the HE courses they attended. André minimized the negative impacts of this barrier by taking longer to complete the course. Julia also felt difficulties related to time. However, she attributes these difficulties specifically to what she regards as an excess in the quantity of academic activities, which she believes to be the result of some disregard for the specific characteristics of NTSs. This issue is of great importance when considering NTS education. It is necessary to invest in support and motivation strategies to prevent drop outs when these students are unable to overcome these difficulties. In fact, André and Julia share time management as one of their main challenges, but with differences in origin and in the way they cope with it.

Another aspect that this research highlighted is related with intergenerational relationships. For Julia, the relationships with her colleagues are true intergenerational conflicts that result in relative distance and isolation. Some challenges faced by NTSs, as compared to traditional students, are also related to institutional culture issues, according to Holmegaard et al. (2017). These authors state that the dynamics of HE that seem to be natural for students who traditionally inhabit the universities can be felt as alien by NTSs. This situation can contribute to these students not feeling like legitimate 
participants. As the biographical-narratives showed, André and Julia moved through this institutional culture in different ways. André, though less experienced with this culture, identified with it, regarding it as legitimate and, within the limitations of his participation, felt integrated. Julia, on the other hand, even though she has more experience with the institutional culture, felt less integrated, predominantly due to relational difficulties she felt when dealing with both teachers and younger colleagues.

As supported by Thunborg et al. (2013), NTS motivations and commitment are an important part of the constitution of their student identities. Identities are part of the students' own construction as students, at a given time, in specific situations, and in relation to different academic contexts (West, 1996). For André and Julia, a student identity committed to HE is evident due to a high degree of intrinsic motivation related to the search for knowledge and self-fulfillment. André sees HE more as an arena for knowledge acquisition and Julia sees it as a way to achieve a life goal.

Focusing on the limitations of this study and what would be interesting to investigate in the future, it can be recognized that the biographical-narrative approach made it possible to understand these NTSs' motivations for entering $\mathrm{HE}$, the challenges they face, and the ways they cope with those challenges.

The motivations, challenges, and strategies that were identified, analyzed, and discussed made it possible to verify the importance of public policies related to the expansion of access and the permanence of NTSs in HE. This study, therefore, reiterates what other studies have already found regarding the role of institutions in these students feeling integrated and in creating the conditions for them to successfully complete their journey (Gilardi \& Guglielmetti, 2011). In addition, it made it possible to identify some issues that may guide future studies, such as the possibility for mutual growth found in intergenerational relationships between traditional students and NTSs; the construction of institutional support and guidance structures for these students; and the impact of academic cultures on NTS involvement in HE, among others.

\section{References}

Amorim, J. P. (2018). Mature students' access to higher education: A critical analysis of the impact of the 23+ policy in Portugal. European Journal of Education, 53(3), 393-413. https:// doi.org/10.1111/ejed.12283

Atkinson, B. (2009). Teachers responding to narrative inquiry: An approach to narrative inquiry criticism. The Journal of Educational Research, 103(2), 91-102. https://doi. org/10.1080/00220670903323461

Bamber, J. (2008, December 10). Foregrounding curriculum: Ditching deficit models of non-traditional students [Paper presentation]. ESREA - Access, Learning Careers and Identities Network Conference, Seville. 
Baptista, A. V. (2013). Non-traditional adult students: Who are they and what are the implications for higher education? Cypriot Journal of Educational Sciences, 8(2), 235-246.

Barros, R., Monteiro, A., \& Sousa, C. (2019). Autoeficácia formativa e envolvimento nos processos de aprendizagem de estudantes portugueses maiores de 23 anos [Formative self-efficacy and involvement in the learning processes of Portuguese students older than 23 years]. Revista Portuguesa de Educação, 32(1), 140-154. https://doi.org/10.21814/rpe.15651

Bolívar Botía, A. (2002). ¿De nobis ipsis silemus? Epistemología de la investigación biográficonarrativa ["De nobis ipse silemus?": Epistemology of biographical-narrative research in education]. Revista Eletrónica de Investigación Educativa, 4(1).

Bolívar Botía, A. (2008). La investigación biográfico-narrativa: Fundamentos y metodología. In M. T. Herrera \& A. E. Gutiérrez (Eds.), Métodos cualitativos de investigación para las ciencias sociales. ITESM.

Brás, J. V., Jezine, E., Fonseca, S., \& Neves Gonçalves, M. (2012). A Universidade Portuguesa: O abrir do fecho de acesso - o caso dos maiores de 23 anos. Revista Lusófona de Educação, 21, 163-178.

Broadhead, S. J. (2018). Mature students, transformation and transition. Education + Training. Advance online publication. https://doi.org/10.1108/ET-02-2018-0035

Broadhead, S. J. (2020). Mature students matter: The impact of the research development fellowship in accessing art and design education. Education Sciences, 10(2), 31. https://doi. org/10.3390/educsci10020031

Bron, A., \& Lönnheden, C. (2004). Higher education for non-traditional students in Sweden: A matter of inclusion. Journal of Adult and Continuing Education: Adult Education and Social Inclusion/Exclusion: Citizen Perspectives, 7, 175-188.

Bruner, J. (1991). The narrative construction of reality. Critical Inquiry, 18(1), 1-21. http:// dx.doi.org/10.1086/448619

Burke, P. J. (2013). The right to higher education: Beyond widening participation. Routledge.

Clandinin, D. J., Cave, M. T., \& Berendonk, C. (2017). Narrative inquiry: A relational research methodology for medical education. Medical Education, 51(1), 89-96. https://doi.org/10.1111/ medu.13136

Cross, K. P. (1981). Adults as learners: Increasing participation and facilitating learning. Jossey-Bass.

Da Cruz, J. C. (2012, September 27). Evolução do fosso digital em Portugal, 1997-2011 [Paper presentation]. X Congresso da LUSOCOM - Comunicação, Cultura e Desenvolvimento, Lisboa.

Davies, P., \& Williams, J. (2003). For Me or Not for Me? Fragility and risk in mature students' decision-making. Higher Education Quarterly, 55(2), 185-203. https://doi.org/10.1111/14682273.00182

de Almeida, A. C. P. F., Quintas, H. L., \& Gonçalves, T. I. C. (2016). Estudantes não-tradicionais no ensino superior: Barreiras à aprendizagem e na inserção professional [Non-traditional students in higher education: Barriers to learning and professional insertion]. Laplage em Revista, 2(1), 97-111. http://dx.doi.org/10.24115/S2446-6220201621122p.97-111

Dhunpath, R. (2000). Life history methodology: "Narradigm" regained. International Journal of Qualitative Studies in Education, 13(5), 543-551. https://doi.org/10.1080/09518390050156459

Edwards, R. (1993). Mature women students: Separating or connecting family and education. Taylor \& Francis.

Elbaz-Luwisch, F. (2005). Teachers' voices: Storytelling and possibility. Information Age Publishing.

Engrácia, P., \& Baptista, J. O. (2018). Percursos no ensino superior: Situação após quatro anos dos alunos inscritos em licenciaturas de três anos. Direção-Geral de Estatísticas da Educação e Ciência. https:// 
www.dgeec.mec.pt $/$ np4 $/ 414 / \% 7 \mathrm{~B} \$$ clientServletPath $\% 7 \mathrm{D} /$ ?newsId=902\&fileName= DGEEC_SituacaoApos4AnosLicenciaturas.pdf

Ferreira, A. M. P. (2011). Estudantes adultos no ensino superior: Contextos e desafios. In L. Alcoforado, J. A. G. Ferreira, A. G. Ferreira, M. P. de Lima, C. Vieira, A. L. Oliveira, \& S. M. Ferreira (Eds.), Educação e formação de adultos: Políticas, práticas e investigação (pp. 201-209). Imprensa da Universidade de Coimbra.

Fragoso, A., \& Valadas, S. T. (2018). Dos “Novos Públicos” do Ensino Superior aos estudantes "não-tradicionais" no Ensino Superior: Contribuições para a construção de um breve mapa do campo. In A. Fragoso \& S. T. Valadas (Eds.), Estudantes não-tradicionais no Ensino Superior (pp. 19-38). CINEP.

Freire, P. (2003). Pedagogia da autonomia: Saberes necessários à prática educativa. Paz e Terra.

Gilardi, S., \& Guglielmetti, C. (2011). University life of non-traditional students: Engagement styles and impact on attrition. Journal of Higher Education, 82(1), 33-53. https://doi. org/10.1353/jhe.2011.0005

Goodson, I. F., Biesta, G., Tedder, M., \& Adair, N. (2010). Narrative learning. Routledge.

Gudmundsdottir, S. (1996). The teller, the tale, and the one being told: The narrative nature of the research interview. Curriculum Inquiry, 26(3), 293-306. https://doi.org/10.1080/036 26784.1996.11075463

Heagney, M., \& Benson, R. (2017). How mature-age students succeed in higher education: Implications for institutional support. Journal of Higher Education Policy and Management, 39(3), 216-234. https://doi.org/10.1080/1360080X.2017.1300986

Hodkinson, P., \& Hodkinson H. (2001, December 5). The strengths and limitations of case study research [Paper presentation]. Learning and skills development conference: Making an impact on policy and practice, Cambridge.

Holmegaard, H. T., Madsen, L. M., \& Ulriksen, L. (2017). Why should European higher education care about the retention of non-traditional students? European Educational Research Journal, 16(1), 3-11. https://doi.org/10.1177/1474904116683688

Johnston R., \& Merrill, B. (2005). Changing learning identities for working-class adult students in higher education. In J. Caldwell \& Centre for Research in Lifelong Learning (Eds.), What a Difference a Pedagogy Makes: Researching Lifelong Learning and Teaching Conference Proceedings, University of Stirling, Scotland, 24-26 June 2005 (pp. 328-334). Centre for Research in Lifelong Learning.

Kirby, P. G., Biever, J. L., Martinez, I. G., \& Gómez, J. P. (2004). Adults returning to school: The impact on family and work. The Journal of Psychology, 138(1), 65-76. https://doi. org/10.3200/JRLP.138.1.65-76

Knapper, C. K., \& Cropley, A. J. (2000). Lifelong learning and higher education. Psychology Press. Liamputtong, P., \& Ezzy, D. (2005). Qualitative research methods. Oxford University Press.

Mangas, C., Lopes, S., Ferreira, P., \& Beato, I. (2019). Accessing higher education after 23 years old: Opportunities and motivations. Cadernos de Pesquisa, 49(172), 36-52. http:// dx.doi.org/10.1590/198053145943

Merrill, B. (2014). Gender and age: Negotiating and experiencing higher education in England. In F. Finnegan, B. Merrill, \& C. Thunborg (Eds.), Student voices on inequalities in European higher education: Challenges for theory, policy and practice in a time of change ( $\left.{ }^{\text {st }} \mathrm{ed} ., \mathrm{pp} .74-85\right)$. Routledge.

Merrill, B. (2015). Determined to stay or determined to leave? A tale of learner identities, biographies and adult students in higher education. Studies in Higher Education, 40(10), 1859-1871. https://doi.org/10.1080/03075079.2014.914918 
Merrill, B., \& Johnston, R. (2011). Access and retention: Experiences of non-traditional learners in bigher education. Literature review. RANLHE.

Mertova, P. (2013). Internationalisation in higher education through a "critical event" narrative inquiry: Perspectives from three higher education systems. Studia Paedagogica, 18(4), 115-128. https://doi.org/10.5817/SP2013-4-7

Molina, R. K. (2011). Cuestiones éticas en torno a la investigación sobre y con historias de vida. In F. Hernández, J. M. Sancho, \& J. I. Rivas (Eds.), Historias de vida en educación: Biografías en contexto (pp. 34-40). ESBRINA-RECERCA/Universitat de Barcelona.

Novotný, P., Brücknerová, K., Juhaňák, L., \& Rozvadská, K. (2019). Driven to be a nontraditional student: Measurement of the academic motivation scale with adult learners after their transition to university. Studia Paedagogica, 24(2), 109-135. https://doi.org/10.5817/ SP2019-2-5

Osborne, M., Marks, A., \& Turner, E. (2004). Becoming a mature student: How adult applicants weigh the advantages and disadvantages of higher education. Higher Education, 48(3), 291-315. https://doi.org/10.1023/B:HIGH.0000035541.40952.ab

Pascueiro, L. (2009). Breve contextualização ao tema da democratização do acesso ao ensino superior: A presença de novos públicos em contexto universitário. Educação, Sociedade e Culturas, 28, 31-52.

Pearce, N. (2017). Exploring the learning experiences of older mature undergraduate students. Widening Participation and Lifelong Learning, 19(1), 59-76. https://doi.org/10.5456/W PLL.19.1.59

Polkinghorne, D. E. (1995). Narrative configuration in qualitative analysis. International Journal of Qualitative Studies in Education, 8(1), 5-23. https://doi.org/10.1080/0951839950080103

Polkinghorne, D. E. (2007). Validity issues in narrative research. Qualitative Inquiry, 13(4), 471-486. https://doi.org/10.1177/1077800406297670

Priestley, M., Biesta, G., \& Robinson, S. (2015). Teacher agency: What is it and why does it matter? In J. Evers \& R. Kneyber (Eds.), Flip the system: Changing education from the ground up (1st ed., pp. 134-148). Routledge.

Quintas, H., Gonçalves, T., Ribeiro, C. M., Monteiro, R., Fragoso, A., Bago, J., Santos, L., \& Fonseca, H. M. (2014). Estudantes adultos no Ensino Superior: O que os motiva e o que os desafia no regresso à vida académica [Adult Students in Higher Education: What motivates and what challenges them in their return to academic life]. Revista Portuguesa de Educação, 27(2), 33-56. https://doi.org/10.21814/rpe.6245

Reay, D., Ball, S., \& David, M. E. (2002). 'It's taking me a long time but I'll get there in the end': Mature students on access courses and higher education choice. British Educational Research Journal, 28(1), 5-19. https://doi.org/10.1080/01411920120109711

Roberts, S. (2011). Traditional practice for non-traditional students? Examining the role of pedagogy in higher education retention. Journal of Further and Higher Education, 35(2), 183-199. https://doi.org/10.1080/0309877X.2010.540320

Rodriguez, T. L., \& Cho, H.-S. (2011). Eliciting critical literacy narratives of bi/multilingual teacher candidates across U.S. teacher education contexts. Teaching and Teacher Education, 27(3), 496-504. https://doi.org/10.1016/j.tate.2010.10.002

Savin-Baden, M., \& Van Niekerk, L. (2007). Narrative inquiry: Theory and practice. Journal of Geography in Higher Education, 31(3), 459-472. https://doi.org/10.1080/03098260601071324

Schuetze, H. G., \& Slowey, M. (2002). Participation and exclusion: A comparative analysis of non-traditional students and lifelong learners in higher education. Higher Education, 44(3-4), 309-327. https://doi.org/10.1023/A:1019898114335 
Schuetze, H. G. (2014). From adults to non-traditional students to lifelong learners in higher education: Changing contexts and perspectives. Journal of Adult and Continuing Education, 20(2), 37-55. https://doi.org/10.7227/JACE.20.2.4

Souto-Otero, M., \& Whitworth, A. (2017). Adult participation in higher education and the 'knowledge economy': A cross-national analysis of patterns of delayed participation in higher education across 15 European countries. British Journal of Sociology of Education, 38(6), 763-781. https://doi.org/10.1080/01425692.2016.1158639

Suárez-Ortega, M. (2013). Performance, reflexivity, and learning through biographical-narrative research. Qualitative Inquiry, 19(3), 189-200. https://doi.org/10.1177/1077800412466223

Taylor, J., \& House, B. (2010). An exploration of identity, motivations and concerns of nontraditional students at different stages of higher education. Psychology Teaching Review, 16(1), 46-57.

Thomas Dotta, L., Lopes, A., \& Leite, C. (2019). O movimento do acesso ao ensino superior em Portugal de 1960 a 2017: Uma análise ecológica [The movement of higher education access in Portugal from 1960 to 2017: An ecological analysis]. Arquivos Analíticos de Políticas Educativas, 27(146), 1-30. https://doi.org/10.14507/epaa.27.4195

Thomas Dotta, L., \& Soares, R. E. (2015). O caráter pedagógico das narrativas biográficas no contexto da abordagem de ensino centrada no estudante [The pedagogical character of the biographical narratives in the context of approach to student-centered learning]. Tendencias Pedagógicas, 25, 261-278. https://doi.org/10.15366/tp2015.25

Thunborg, C., Bron, A., \& Edström, E. (2013). Motives, commitment and student identity in higher education - Experiences of non-traditional students in Sweden. Studies in the Education of Adults, 45(2), 177-193. https://doi.org/10.1080/02660830.2013.11661650

Tumuheki, P. B., Zeelen, J., \& Openjuru, G. L. (2016). Motivations for participation in higher education: Narratives of non-traditional students at Makerere University in Uganda. International Journal of Lifelong Education, 35(1), 102-117. https://doi.org/10.1080/02601370. 2016.1165745

West, L. (1996). Beyond fragments: Adults, motivation and higher education. Taylor \& Francis.

\section{Corresponding authors}

Leanete Thomas Dotta

CIIE/Faculty of Psychology and Education Sciences, University of Porto, Portugal

E-mail: leanete@fpce.up.pt

Carlinda Leite

CIIE/Faculty of Psychology and Education Sciences, University of Porto, Portugal

E-mail: carlinda@fpce.up.pt

Amélia Lopes

CIIE/Faculty of Psychology and Education Sciences, University of Porto, Portugal E-mail: amelia@fpce.up.pt 